
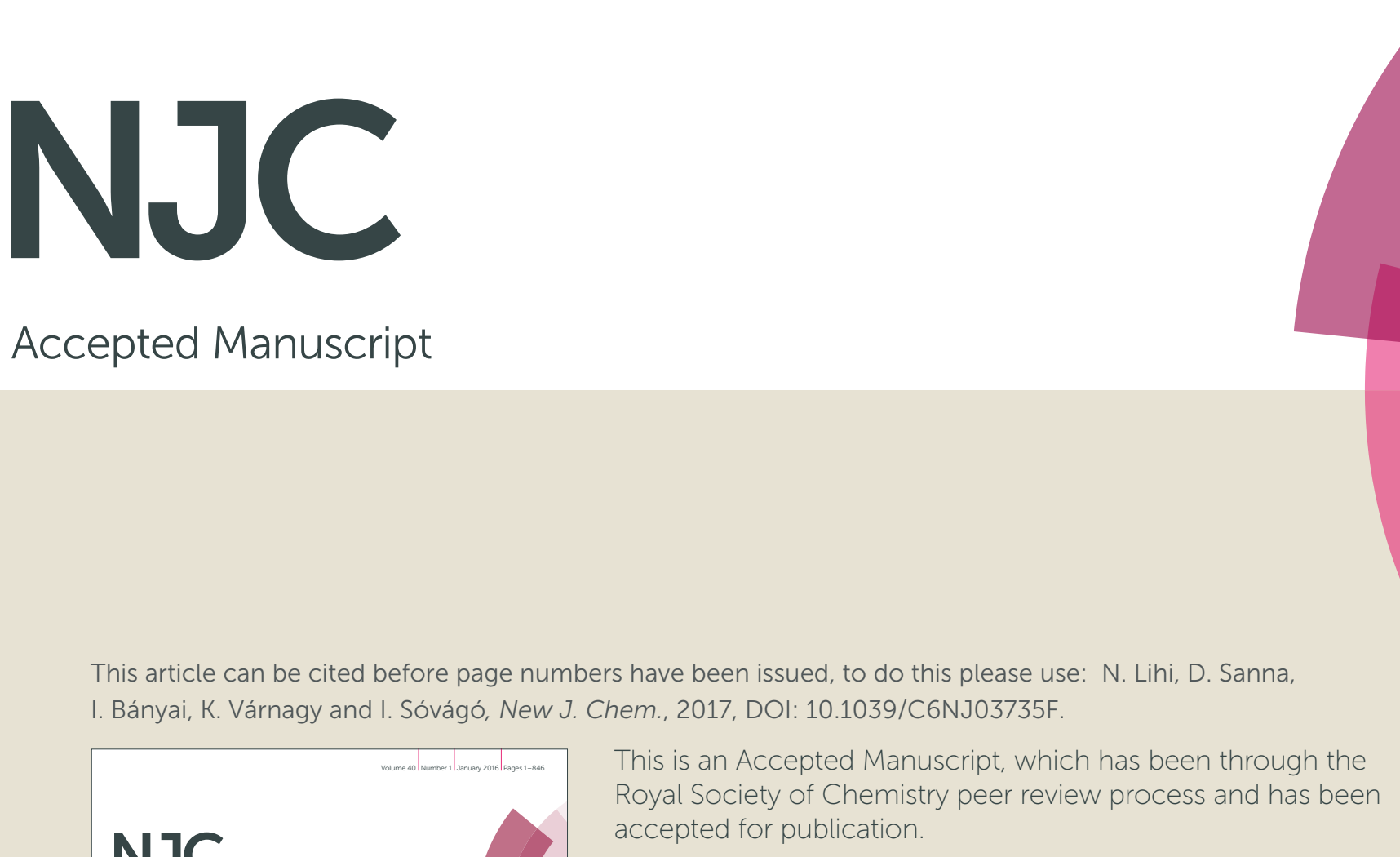

This article can be cited before page numbers have been issued, to do this please use: N. Lihi, D. Sanna,

I. Bányai, K. Várnagy and I. Sóvágó, New J. Chem., 2017, DOI: 10.1039/C6NJ03735F.

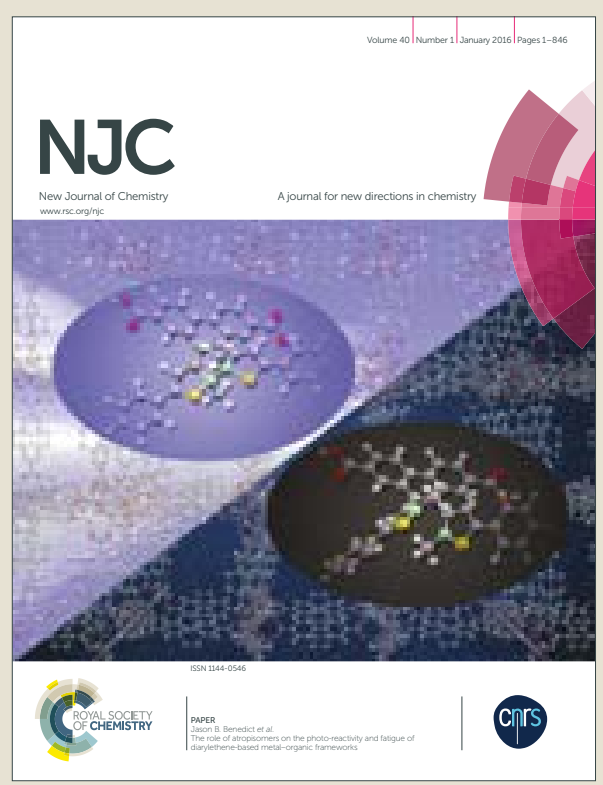

This is an Accepted Manuscript, which has been through the Royal Society of Chemistry peer review process and has been accepted for publication.

Accepted Manuscripts are published online shortly after acceptance, before technical editing, formatting and proof reading. Using this free service, authors can make their results available to the community, in citable form, before we publish the edited article. We will replace this Accepted Manuscript with the edited and formatted Advance Article as soon as it is available.

You can find more information about Accepted Manuscripts in the author guidelines.

Please note that technical editing may introduce minor changes to the text and/or graphics, which may alter content. The journal's standard Terms \& Conditions and the ethical guidelines, outlined in our author and reviewer resource centre, still apply. In no event shall the Royal Society of Chemistry be held responsible for any errors or omissions in this Accepted Manuscript or any consequences arising from the use of any information it contains. 


\section{Unusual binding modes in the copper(II) and palladium(II) complexes of peptides containing both histidyl and cysteinyl residues ${ }^{\dagger}$}

Received 00th January 20xx, Accepted 00th January 20xx

DOI: $10.1039 / x 0 x \times 00000 x$

www.rsc.org/

\section{Norbert Lihi*a ${ }^{*}$ Daniele Sanna ${ }^{\mathrm{b}}$, István Bányai ${ }^{\mathrm{c}}$, Katalin Várnagy ${ }^{\mathrm{a}}$ and Imre Sóvágóa}

Two N-terminally free but C-terminally amidated peptides containing both histidine and cysteine (AAHAAC-NH 2 and AHAAAC- $\mathrm{NH}_{2}$ ) have been synthesized and copper(II) and palladium(II) complexes were studied by potentiometric, various spectroscopic methods and DFT calculations. In the case of copper(II)-AAHAAC- $\mathrm{NH}_{2}$ system the $\left(\mathrm{NH}_{2}, \mathrm{~N}^{-}, \mathrm{N}^{-}, \mathrm{N}_{\text {im }}\right)$ coordination mode hindered the interaction between copper(II) and the thiolate preventing the redox reactions in acidic and neutral solution. The supress of redox reactions between copper(II) ions and the peptide $A$ HAAAC-NH $\mathrm{N}_{2}$ was also observed in equimolar samples but in this case the existence of $\mathrm{Cu}(\mathrm{II})-\mathrm{S}$ (thiolate) binding was detected in the physiological $\mathrm{pH}$ range. For palladium(II) complexes the results unambiguously prove the predominance of Pd-S(thiolate) binding mode over the formation of the Pd-N(amide) bonds even if the thiolate residues are involved in various macrochelates only. The thiolate group of cysteinyl residue was described as the primary ligating site of both peptides and the remaining coordination sites were occupied by the amino, imidazole and one amide nitrogen donor atoms in the palladium(II) complexes.

\section{Introduction}

Oligopeptides are effective ligands to bind metal ions. ${ }^{1}$ The metal binding affinity of peptides is, however, rather selective and largely depends on the side chain donors of peptides and the character of metal ions. As a consequence, the peptide sequence significantly can determine the metal binding ability. For studying these effects the investigation of short oligopeptide fragments is indispensable, therefore, huge number of peptides have been widely studied with transition metal ions and the results are collected in several reviews. ${ }^{2-5}$

The formation of stable metal complexes of peptides is generally connected to the deprotonation and coordination of amide nitrogens. Several metal ions, such as copper(II), nickel(II) and palladium(II), are able to promote this coordination, although, palladium(II) was reported as one of the most effective metal ion in this interaction. ${ }^{6}$ The previous studies also reveal that among the various side chain residues imidazole- $\mathrm{N}$ of histidine and thiolate-S of cysteine are the most common metal binding sites.

Metal complexes of (multi)histidine peptides have been widely studied because the development of various forms of neurodegenerative disorders is linked to these molecules. The studies on cysteine containing peptides are much less available, the most important findings are related to nickel(II) homeostasis of Helicobacter pylori 7,8 and to the zinc(II) transporters and zinc finger proteins. ${ }^{9,10}$ Furthermore, stable copper(II)-thiolate coordination was reported in blue copper proteins including plastocyanin. Here, copper(II) has distorted tetrahedral geometry with $2 x \mathrm{His}(\mathrm{im})$, amide nitrogen and thiolate of cysteine coordination environment. ${ }^{11}$ This copper(II) metal binding loop of plastocyanin have also been widely studied with different type of spectroscopic methods. The binding of the thiolate results in a drastic change in the electronic and EPR parameters and increases the reduction potential of $\mathrm{Cu}(\mathrm{II}) / \mathrm{Cu}(\mathrm{I})$ system. ${ }^{12}$ As shown, peptides with multiple and different binding sites allow for the possibility of great structural variety in complex formation and may contribute to the better understanding of the metal ion selectivity of peptides.

Based on these facts, systematic studies have been performed in our lab to synthesize $\mathrm{N}$-terminally free but C-terminally amidated oligopeptides containing cysteine and other strongly coordinating residues, histidine or another cysteine. ${ }^{13}$ The complex formation processes of the synthesized peptides (AAHAAC- $\mathrm{NH}_{2}$ and AHAAAC- $\mathrm{NH}_{2}$, Scheme 1 ) have already been studied with nickel(II), zinc(II) and cadmium(II) ions that was reported in our previous paper. ${ }^{14}$ Our results indicated that the binding of the thiolate largely depends on the position of the other donor groups in the peptide chain. It means that in the case of nickel(II)-AAHAAC-NH $\mathrm{NH}_{2}$ system the formation of albumin-like coordinated species is favorable and the coordination of the thiolate could be suggested only in dinuclear complexes. In contrast, nickel(II) and zinc(II) complexes of AHAAAC- $\mathrm{NH}_{2}$ are easily formed with $\left(\mathrm{NH}_{2}, \mathrm{~N}^{-}, \mathrm{N}_{\mathrm{im}}\right)$ binding mode resulting in unsaturated coordination sphere that can be completed with macrochelation from the distant thiolate group. To continue our work, the complex formation processes

\footnotetext{
a. Department of Inorganic and Analytical Chemistry, University of Debrecen, $\mathrm{H}$ 4032, Debrecen, Hungary. E-mail: lihi.norbert@science.unideb.hu

b. Istituto CNR di Chimica Biomolecolare, Trav. La Crucca, 3, I-07040 Sassari, Italy

Department of Physical Chemistry, University of Debrecen, H-4032, Debrecen, Hungary. 
<smiles>CC(N)C(=O)NC(C)C(=O)NC(Cc1c[nH]cn1)C(=O)NC(C)C(=O)NC(C)C(=O)NC(CS)C(N)=O</smiles><smiles>CC(N)C(=O)NC(Cc1c[nH]cn1)C(=O)NC(C)C(=O)NC(C)C(=O)NC(C)C(=O)NC(CS)C(N)=O</smiles>

Scheme1. Structural formulae of the ligands

of these peptides with copper(II) and palladium(II) are reported. Copper(II) complexes with peptides containing histidine residue in the third position are able to form albumin-like complexes with outstanding stability because of the formation of fused $(5,5,6)$-membered chelate system (ATCUN motif). This binding mode can be suggested in the case of AAHAAC- $\mathrm{NH}_{2}$. On the other hand thiolate residues may reduce copper(II) ions but coordination of imidazole residues may affect the redox reactions. In case of copper(II)-AHAAAC- $\mathrm{NH}_{2}$ system, the characteristic coordination mode of the $\mathrm{N}$-terminus is unsaturated $\left(\mathrm{NH}_{2}, \mathrm{~N}^{-}, \mathrm{N}_{\mathrm{im}}\right)$ providing a chance either for binding or redox reactions of the thiolate function. Palladium(II), however, prefers the coordination of various S-donor ligands and it may influence the characteristic coordination modes of the histidyl parts of the molecules.

\section{Experimental and computational methods}

\section{Peptide synthesis, purification and other materials}

$\mathrm{N}$-terminally free but $\mathrm{C}$-terminally amidated peptides (AAHAAC$\mathrm{NH}_{2}$ and AHAAAC- $\mathrm{NH}_{2}$ ) were synthesized by solid phase peptide synthesis using a microwave assisted Liberty 1 Peptide Synthesizer (CEM, Matthews, NC). F-moc chemistry was used to synthesize the peptides and their purifications were checked by reverse-phase HPLC, ${ }^{1} \mathrm{H}$ NMR and mass spectrometry. Exact description about the synthesis and purifications was described in our previous publication. ${ }^{14}$

Stock solution of metal ions (palladium(II) and copper(II)) were prepared from $\mathrm{K}_{2}\left[\mathrm{PdCl}_{4}\right]$ and $\mathrm{CuCl}_{2}$ and their concentration were checked gravimetrically. In the case of palladium(II) stock solution, two equivalents of $\mathrm{HCl}$ were added to avoid hydrolytic processes. The concentration of the acid in the palladium(II) stock solution was checked by GRAN method. ${ }^{15}$

\section{Potentiometric measurements}

The $\mathrm{pH}$-potentiometric titrations were accomplished in $3.00 \mathrm{~mL}$ samples at $2 \mathrm{mM}$ total ligand concentration with the use of carbonate free stock solution (0.2 M) of potassium hydroxide. The metal to ligand ratio was selected as 1:1. During the titrations, argon was bubbled through the samples to ensure the absence of oxygen and carbon dioxide. The samples were stirred by a VELP scientific magnetic stirrer.
Titrations were carried out at $298 \mathrm{~K}$, the constant ionic strength

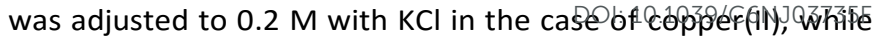
$\mathrm{KNO}_{3}$ was used for palladium(II) to suppress the formation of mixed chlorido complexes.

The $\mathrm{pH}$ measurements were performed with a MOLSPIN pHmeter equipped with a 6.0234.100 combination glass electrode (Metrohm) and a titrant was dosed by means of a MOL-ACS burette controlled by computer. The recorded $\mathrm{pH}$ readings were converted to hydrogen ion concentration as described by Irving et al. ${ }^{16}$ Protonation constants of the ligands and the overall stability constants $\left(\lg \beta_{\text {pqr }}\right)$ of the metal complexes were calculated by means of general computational programs, SUPERQUAD ${ }^{17}$ and PSEQUAD ${ }^{18}$. Equilibrium constants were defined using eqn. (1) and (2):

$$
\begin{array}{r}
\mathrm{pM}+\mathrm{qL}+\mathrm{rH}=\mathrm{M}_{\mathrm{p}} \mathrm{L}_{\mathrm{q}} \mathrm{H}_{\mathrm{r}} \\
\beta_{p q r}=\frac{\left[M_{p} L_{q} H_{r}\right]}{[M]^{p} \cdot[L]^{q} \cdot[H]^{r}}
\end{array}
$$

\section{Spectroscopic studies}

UV-visible spectra of the copper(II) and palladium(II) complexes were recorded from 200 to $1000 \mathrm{~nm}$ range on a PerkinElmer Lambda 25 scanning spectrophotometer. Circular dichroism spectra of the complexes were registered on a JASCO 1-810 spectropolarimeter using $1 \mathrm{~mm}$ and/or $1 \mathrm{~cm}$ cells in the 200$1000 \mathrm{~nm}$ wavelength range.

Anisotropic EPR spectra were recorded on a Bruker EMX spectrometer equipped with a HP 53150A microwave frequency counter at $120 \mathrm{~K}$. Copper(II) stock solution for EPR measurements were prepared from $\mathrm{CuSO}_{4} \cdot 5 \mathrm{H}_{2} \mathrm{O}$ that had been enriched with ${ }^{63} \mathrm{Cu}$ (JV Isoflex, Moscow, Russia) to achieve higher resolution of spectra.

$400 \mathrm{MHz}{ }^{1} \mathrm{H}$ NMR spectra were recorded on a Bruker Avance 400 spectrometer at $298 \mathrm{~K}$. The chemical shifts were referenced to internal sodium 3-(trimethylsilyl)-1-propane sulfonate (TSP, $\delta_{\text {TSP }}=0 \mathrm{ppm}$ ) and $\mathrm{D}_{2} \mathrm{O}$ was used as a solvent. Diffusion NMR measurements were carried out with pulse field gradient stimulated spin echo sequence (PGSE). Longitudinal eddycurrent delay (LED) and bipolar gradient pulses were used in the standard pulse sequence available in the spectrometer. ${ }^{19}$ In the experiments constants diffusion time $(\Delta=80 \mathrm{~ms})$ was used and gradient pulse length ( $\delta), 2 \mathrm{~ms}$. The pulsed gradient strength (G) increased with 32 square distant steps from 0 to approximately 50 Gauss $\cdot \mathrm{cm}^{-1}$. The diffusion coefficient was determined from the attenuation of echo signals by increasing the pulsed gradient strength $(\mathrm{G})$. The integrated intensity of the methylene of cysteine and methyl signals of alanine around $1 \mathrm{ppm}$ was used for the evaluation. The diffusion coefficient was calibrated by using the known diffusion coefficient of $\mathrm{D}_{2} \mathrm{O}$ at $298 \mathrm{~K} .{ }^{20}$ To determine the hydrodynamic radii $\left(R_{H}\right)$ from the diffusion coefficients of the species, Stokes-Einstein equation was used.

\section{DFT methods}

DFT calculations have been performed to optimize the geometry of the palladium complexes and calculate the relative free energy. All calculations were performed using the Gaussian 09 (revision. C.01) software package. ${ }^{21}$ The first step was full ground state geometry optimization using B3LYP 22 hybrid type 
exchange correlation-functional with the basis set 6-311g(d) on $\mathrm{C}, \mathrm{H}, \mathrm{N}, \mathrm{O}, \mathrm{S}, \mathrm{Cu}(\mathrm{II})$ and LANL2DZ on Pd(II). The following step was frequency calculation to calculate the relative free energy with the same functional and basis set. In all cases, PCM solvent model was used to account for the effect of water. PCM model is available in Gaussian 09 software. Thermal contribution at $298 \mathrm{~K}$ with zero-point energy was included in the calculations. In order to predict ECD spectra TD-DFT ${ }^{23}$ was used and two different functional (BHandHLYP 24 and CAM-B3LYP25) have been tested with the same basis set described earlier. The calculations were carried out on the geometry optimized in water. The electronic circular dichroism spectra were generated by using Multiwfn software ${ }^{26}$. ECD spectra were generated as a sum of Gaussian curves with $0.6 \mathrm{eV}$ half-height width.

\section{Results and discussion}

The acid-base properties of the ligands have been determined by means of $\mathrm{pH}$-potentiometry and ${ }^{1} \mathrm{H}$ NMR spectroscopy in our previous paper. ${ }^{14}$ These results indicated that the following deprotonation order could be calculated: $\mathrm{pK}\left(\mathrm{His}_{\mathrm{im}}\right)<\mathrm{pK}\left(\mathrm{NH}_{3}{ }^{+}\right)<$ $<\mathrm{pK}(\mathrm{SH})$.

\section{Copper(II) complexes of AAHAAC- $\mathrm{NH}_{2}$}

In the presence of copper(II) the equilibrium studies have been performed in the slightly acidic $\mathrm{pH}$ range $(\mathrm{pH} 3.6-7.0)$ to avoid the possible redox reaction and in the basic $\mathrm{pH}$ range the complex formation processes were characterized from structural point of view. In the slightly acid $\mathrm{pH}$ range the copper(II):AAHAAC- $\mathrm{NH}_{2}$ speciation is simple, only one species could be detected, namely, the $\mathrm{CuLH}_{-1}$ complex. Previous studies indicated that the $\mathrm{N}$-terminally free peptides containing histidine in the third position ( $\mathrm{NH}_{2}$-Xaa-Yaa-His- sequences) are able to form a fused $(5,5,6)$-membered chelate with outstanding copper(II) and nickel(II) binding ability, it is the socalled ATCUN motif. ${ }^{27}$ In our case the peptide sequence corresponds well to that of albumin that indicates the possibility of formation of $\left(\mathrm{NH}_{2}, \mathrm{~N}^{-}, \mathrm{N}^{-}, \mathrm{N}_{\mathrm{im}}\right)$-coordinated species. The lack of the CuLH and CuL complexes strongly suggested the cooperative deprotonation of two adjacent peptide amide group, while the thiol group is protonated $\left(\mathrm{CuLH}_{-1}=\mathrm{Cu}\left(\mathrm{LH}_{-2}\right) \mathrm{H}\right)$. Stability constant of $\mathrm{CuLH}_{-1}$ is 8.00 (6) from $\mathrm{pH}$-potentiometric data. Equilibrium constant for the formation of the $\left(\mathrm{NH}_{2}, \mathrm{~N}^{-}, \mathrm{N}^{-}\right.$ , $\mathrm{N}_{\mathrm{im}}$ ) coordination mode can be obtained using the following equation where the $\mathrm{pK}$ value of the non-coordinated thiol function is subtracted:

$\log \mathrm{K}_{\text {ATCUN-like }}=\lg \beta\left(\mathrm{CuLH}_{-1}\right)-\mathrm{pK}(\mathrm{SH})=-0.77$.

This value is very close to those reported for the copper(II) complexes of AAHAAHG $\left(\log K_{\text {ATCUN-like }}=\lg \beta\left(\mathrm{CuLH}_{-1}\right)-\right.$ $\left.\operatorname{pK}(\mathrm{His}(\mathrm{im}))=-0.82^{28}\right)$. These values strongly support the same coordination mode. ${ }^{27,28}$

UV-vis absorption spectra of the $\mathrm{Cu}(\mathrm{II})$ :AAHAAC- $\mathrm{NH}_{2}$ are plotted in Figure 1 as a function of $\mathrm{pH}$. In good agreement with the distribution curves, the complex formation processes started around $\mathrm{pH}$ 4.6. Absorption spectra clearly indicate that the $\mathrm{CuLH}_{-1}$ species is $\left(\mathrm{NH}_{2}, \mathrm{~N}^{-}, \mathrm{N}^{-}, \mathrm{N}_{\mathrm{im}}\right)$-coordinated and the thiolate is non-coordinated, although, the deprotonation of the thiolate

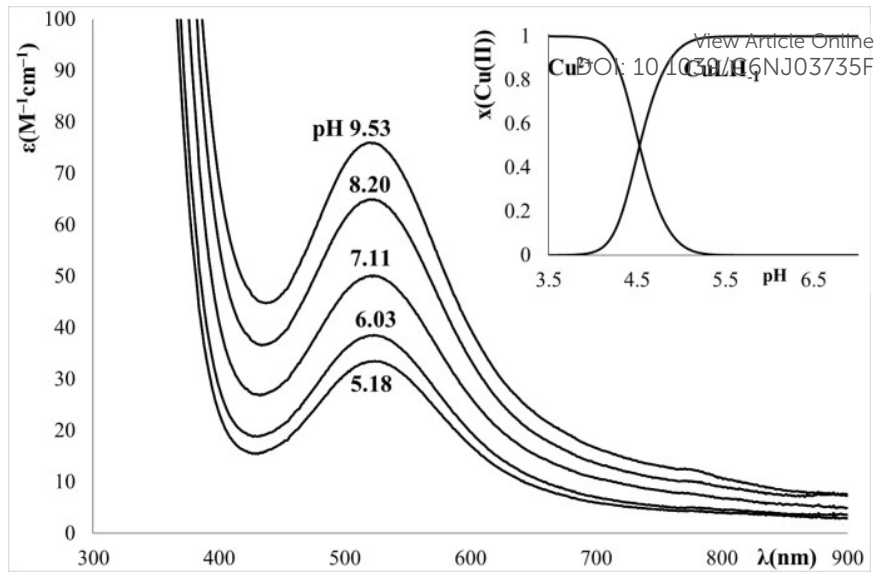

Figure 1. UV-vis spectra and concentration distribution curve of $\mathrm{Cu}(\mathrm{II})$ :AAHAAC- $\mathrm{NH}_{2}$ 1:1 system. $\mathrm{C}_{\mathrm{L}}=1 \mathrm{mM}$

group results in increasing of the intensity of spectra. The electronic parameters $\left(\lambda=522 \mathrm{~nm}\right.$ and $\left.\varepsilon=75.9 \mathrm{M}^{-1} \cdot \mathrm{cm}^{-1}\right)$ corresponds well to that of albumin-like coordinated copper(II) complex. ${ }^{28}$ Electronic CD spectra of the equimolar samples provided further support for this assumption and the lack of the thiolate-bounded complex (Figure S1).

EPR spectra of $\mathrm{Cu}(\mathrm{II})$ :AAHAAC-NH $\mathrm{NH}_{2}$ 1:1 system are plotted in Figure 2. The EPR parameters are in good agreement with the albumin-like coordination. Change of the EPR intensity could not be detected by increasing $\mathrm{pH}$ supporting the lack of the redox reactions between the thiolate group and copper(II) ions. Moreover, EPR spectra clearly show that the coordination of thiolate group is not possible because in the alkaline $\mathrm{pH}$-range the EPR parameters are the same to those measured in slightly acid $\mathrm{pH}$. It means that the saturation of the coordination environment of copper(II) is able to hinder the redox reactions between the thiolate group and copper(II) in acidic and neutral solution.

\section{Palladium(II) complexes of AAHAAC- $\mathrm{NH}_{2}$}

In the presence of palladium(II) the complex formation processes are significantly different. Three species could be calculated on the basis of equilibrium data. However, exact determination of the stability constants is not possible because

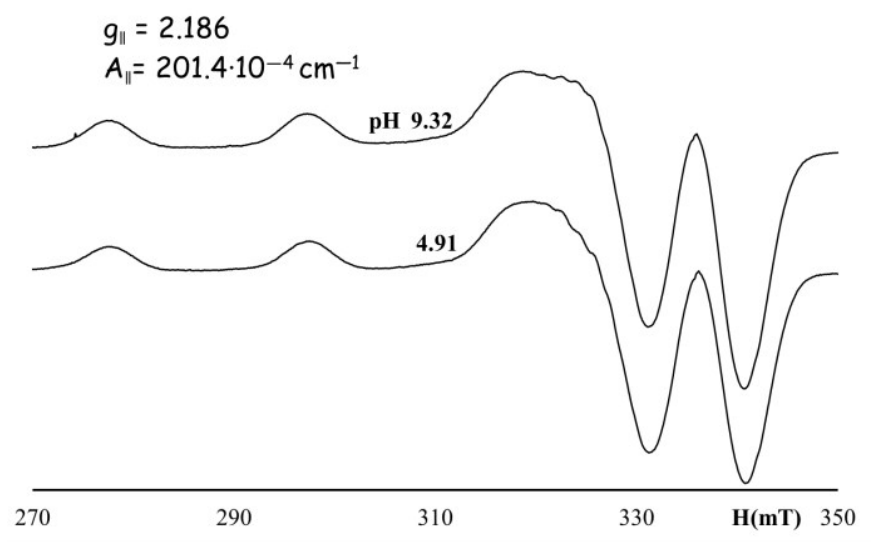

Figure 2. EPR spectra of $\mathrm{Cu}(\mathrm{II}): \mathrm{AAHAAC}-\mathrm{NH}_{2} \quad 1: 1$ system as a function of $\mathrm{pH} . \mathrm{c}_{\mathrm{L}}=1 \mathrm{mM}$. 


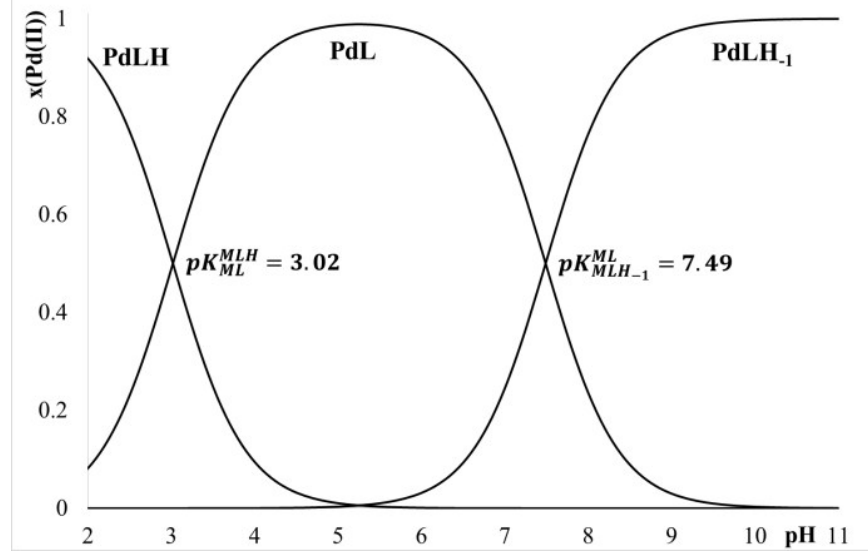

Figure 3. Concentration distribution curve of the palladium(II):AAHAAC- $\mathrm{NH}_{2} \quad 1: 1 \quad$ system. The stepwise protonation constants are also marked.

of the high stability of PdLH complex. In this case only the lower limit of the stability constant of MLH could be given which is 24.0. Based on this fact, only stepwise protonation constants could be calculated. In the case of PdLH complex, the histidine and thiolate group are coordinated by palladium(II) and the $\mathrm{N}$ terminal ammonium group is protonated. Similar tendencies have been observed in the zinc(II)- and cadmium(II)-AAHAAC$\mathrm{NH}_{2}$ system. ${ }^{14}$ The following step is the deprotonation and coordination of the ammonium group resulting in $\left(\mathrm{NH}_{2}, \mathrm{~N}_{\mathrm{im}}, \mathrm{S}^{-}\right)$ coordinated species (PdL). This species is dominant in a wide $\mathrm{pH}$ range (see Figure 3 ) and able to suppress the ionization and metal ion coordination of peptide amide bond. This feature of palladium(II) is unusual because of the high affinity for the metal promoted deprotonation and coordination of peptide nitrogen. $C D$ spectra obviously prove the lack of the amide nitrogen coordinated species below $\mathrm{pH} 6.0$ because the low intensity of $\mathrm{CD}$ spectra excludes the contribution of amide coordination. $\mathrm{pH}$-potentiometric titrations showed only one equivalent extrabase consumption process in the $\mathrm{Pd}(\mathrm{II})$ :AAHAAC- $\mathrm{NH}_{2}$ 1:1 metal to ligand ratio system. This observation is slightly surprising if one takes into account the high affinity of palladium(II) for the formation of fused $(5,5,6)$-membered chelate system containing two deprotonated amide functions. However, the coordination of the thiolate group is able to hinder the formation of this chelate system resulting in the species $\mathrm{PdLH}_{-1}$ with one amide in the coordination sphere $\left(\mathrm{NH}_{2}, \mathrm{~N}^{-}, \mathrm{N}_{\text {im }}\right)$ and supported by macrochelation of thiolate from the C-termini. The deprotonation and coordination of peptide amide occurs in

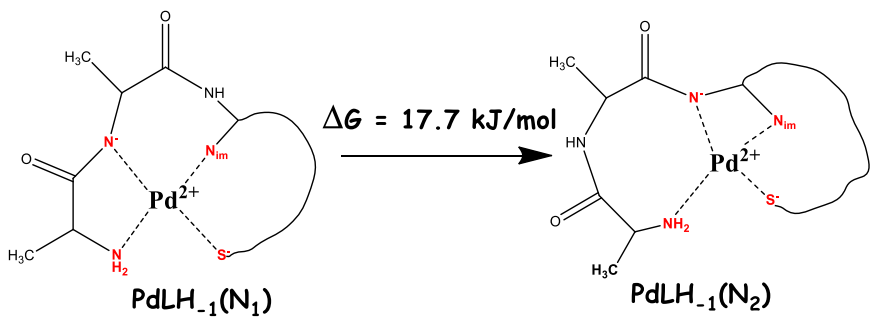

Scheme 2. Scheme of the calculation of relative free energy between two coordination isomers.

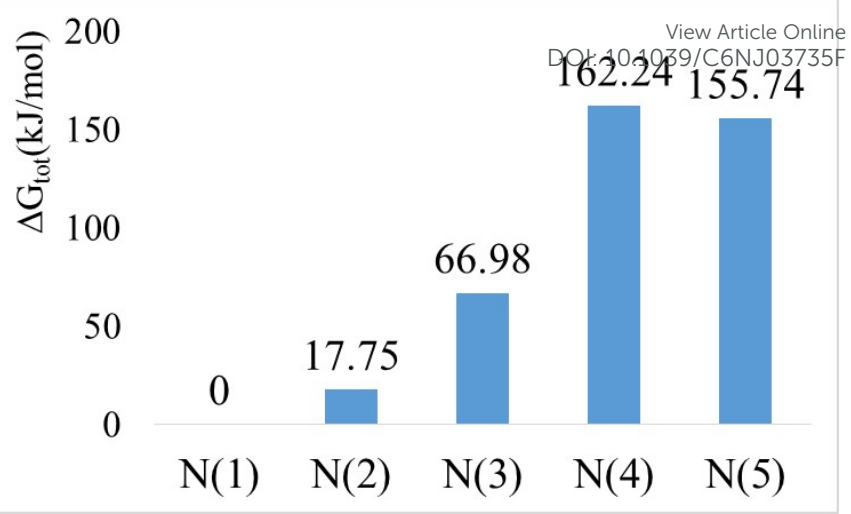

Figure 4. Calculated relative free energies of different coordination isomers of $\mathrm{PdLH}_{-1}$ complex (L: AAHAAC- $\mathrm{NH}_{2}$ ).

neutral solution $\left(\mathrm{pK}\left(\mathrm{ML} / \mathrm{MLH}_{-1}\right)=7.49\right)$ with the formation of $\mathrm{PdLH}_{-1}$, and concomitant increase of $\mathrm{CD}$ intensity. Only a few circular dichroism data are available for the palladium(II)peptide complexes but the increase of the intensity of $C D$ extrema seems to be a clearcut evidence for the amide coordination. ${ }^{29}$ However, a series of various coordination isomers can exist with the involvement of the $\left(\mathrm{NH}_{2}, \mathrm{~N}^{-}, \mathrm{N}_{\mathrm{im}}, \mathrm{S}^{-}\right)$ donor groups. DFT and TD-DFT calculations have been performed to get information on the preference for the formation of these coordination isomers. Five different coordination isomers with $\left(\mathrm{NH}_{2}, \mathrm{~N}^{-}, \mathrm{N}_{\mathrm{im}}, \mathrm{S}^{-}\right)$donor groups have been calculated where the position of the coordinated amide nitrogen was changed. The relative free energies of the coordination isomers were plotted in Figure 4 on the base of following equation:

$$
\Delta \mathrm{G}_{\text {tot }}\left[\mathrm{PdLH}_{-1}\left(\mathrm{~N}_{1}\right)\right] \rightleftharpoons \Delta \mathrm{G}_{\text {tot }}\left[\mathrm{PdLH}_{-1}\left(\mathrm{~N}_{1 . . .5}\right)\right]
$$

where the position of the coordinated amide nitrogen in the peptide backbone is marked by $1,2,3,4,5$.

Scheme 2 representatively shows the method of the calculation of relative free energy where the difference of free energy was calculated between the firstly and secondly coordinated amide nitrogen species.

Based on Figure 4, positive relative free energy means that the formation of that coordination isomer is not favorable.

The values of the relative free energies clearly indicate that the most stable coordination isomer is the first amide nitrogen coordinated species. In this case the coordination of the $\mathrm{N}(1)$ amide nitrogen result in more favorable $\Delta G_{\text {tot }}$ value, with optimal $\mathrm{Pd}-\mathrm{NH}_{2}, \mathrm{Pd}-\mathrm{N}(1)$ and $\mathrm{Pd}-\mathrm{S}^{-}$distances. The distances and angles of the five coordination isomers are summarized in Table 1 and supplemented with single-crystal X-ray data of $\mathrm{Pd}(\mathrm{II})$ :Glycil-glycil-histidine. ${ }^{30}$

The optimized structure of this complex is plotted in Figure 5. In contrast with the copper(II) complex of AAHAAC (optimized structure of the copper(II) complex is also plotted in Figure 5), where the albumin-like coordination is favorable, in the presence of palladium(II) the coordination of thiolate results in rigid structure that can be stabilized by the formation of intramolecular hydrogen bond between the $\mathrm{N}(4) \mathrm{H}$ and amide function on the C-termini. 


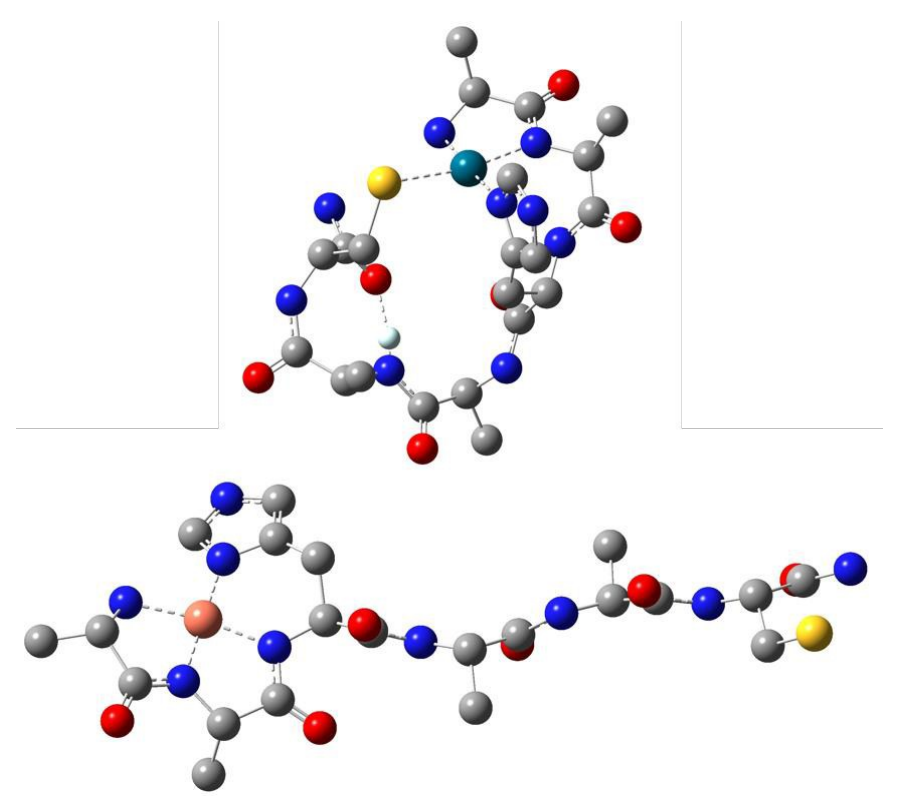

Figure 5. Optimized structures of the palladium(II) (top) and copper(II) (bottom) complexes with AAHAAC- $\mathrm{NH}_{2}$ ligand formed at physiological $\mathrm{pH}$.

To give further evidence about the most stable coordination isomer TD-DFT was used to predict the ECD spectra of palladium(II) complexes. It has been recently reported that TDDFT is an useful method to predict ECD spectra in copper(II) and nickel(II) peptide systems ${ }^{31}$ and TD-DFT calculations were reported in the case of ECD spectra of cobalt(II) and chromium(III) complexes ${ }^{32}$ as well. A very good agreement with the experimental spectra has been found by using CAM-B3LYP functional. The experimental and calculated ECD spectra are plotted in Figure 6 and the other calculated ECD spectra of coordination isomers are available in ESI (Figure S2). This calculation clearly suggests the preference of the first amide nitrogen coordinated palladium(II) complex.

Nevertheless, the formation of oligomeric species of the palladium(II) complexes with thiol containing ligands is well known. ${ }^{33,34}$ Based on this fact, diffusion NMR measurements

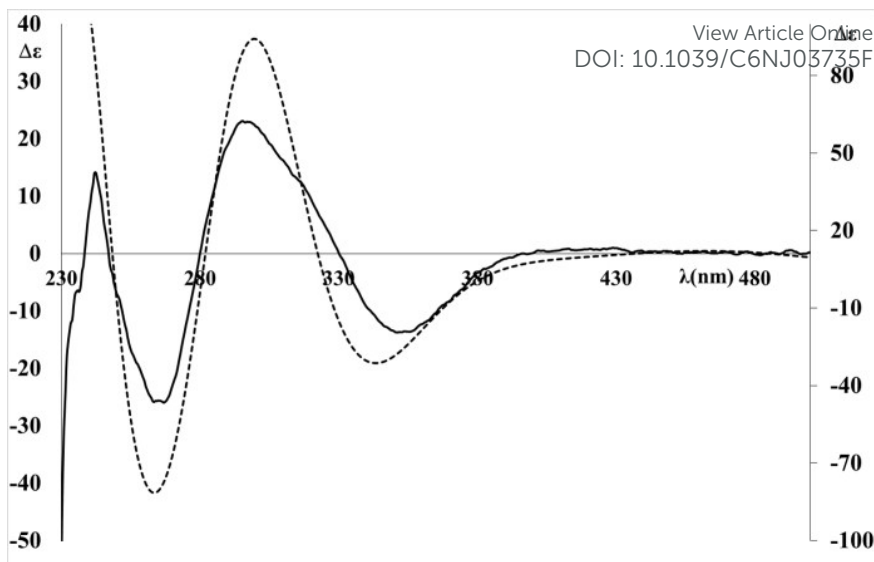

Figure 6. Experimental (solid line) and calculated (dashed line) ECD spectra of the $\mathrm{PdLH}_{-1}$ complex for the $\mathrm{N}(1)$ structure.

were performed at $\mathrm{pH} 9.8$ with the ligand and the palladium(II) complex by using two different concentrations ( $1 \mathrm{mM}$ and 5 $\mathrm{mM}$ ). Diffusion coefficient of the ligand is $D=3.35(7) \times 10^{-10}$ $\mathrm{m}^{2} \cdot \mathrm{s}^{-1}$ from which the apparent hydrodynamic radius could be calculated as $0.73 \mathrm{~nm}$. This relatively small size could be explained by the involvement of intramolecular hydrogen bond. In our previous study with cysteine and serine containing heptapeptide (ACSSACS- $\mathrm{NH}_{2}$ ), the same parameter was 0.6 $\mathrm{nm} \cdot{ }^{13}$ However, the existence of the serine amino acids increases the possibility of the formation of intramolecular hydrogen bond resulting in more rigid coil like structure. The coordination of the palladium(II) results in the change of the diffusion coefficients but it is important to note that in the measurable concentration range these parameters are in good agreement with each other, namely $D_{1 \mathrm{mM}}=1.61(2) \times 10^{-10} \mathrm{~m}^{2} \cdot \mathrm{s}^{-}$ ${ }^{1}$ and $D_{5 \mathrm{mM}}=1.58(1) \times 10^{-10} \mathrm{~m}^{2} \cdot \mathrm{s}^{-1}$. The values correspond to the hydrodynamic radii $R_{P d}=1.53(2) \mathrm{nm}$. This increase in size supports that the coordination of the palladium is able to remove or break the intramolecular hydrogen bonds, however, this relatively small increase in the size can rule out the possibility of the formation of polymer species. From the optimized structure of the palladium(II) complex, a hypothetical radii could be calculated which is approximately $1.17 \mathrm{~nm}$. In general, NMR diffusiometry indicated that during the

Table 1. Geometrical parameter calculated by DFT methods for the Pd(II) - complexes.

\begin{tabular}{|c|c|c|c|c|c|c|c|}
\hline \multirow{2}{*}{ Distance/anglea } & \multicolumn{5}{|c|}{$\mathrm{Pd}(\mathrm{II}):$ AAHAAC- $\mathrm{NH}_{2}\left[\mathrm{MLH}_{-1}\right]$} & \multirow{2}{*}{$\begin{array}{l}\mathrm{Pd}(\mathrm{II}): \mathrm{GGH} \\
{\left[\mathrm{MLH}_{-2}\right]^{\mathrm{b}}}\end{array}$} & \multirow{2}{*}{$\begin{array}{c}\mathrm{Pd}(\mathrm{II}): \text { AHAAAC }-\mathrm{NH}_{2} \\
{\left[\mathrm{MLH}_{-1}\right]}\end{array}$} \\
\hline & Isomer 1 & Isomer 2 & Isomer 3 & Isomer 4 & Isomer 5 & & \\
\hline $\mathrm{Pd}-\mathrm{NH}_{2}$ & 206.8 & 211.6 & 215.1 & 217.6 & 217.5 & 205.8 & 208.2 \\
\hline $\mathrm{Pd}-\mathrm{N}^{-}$ & 211.7 & 212.1 & 215.5 & 228.6 & 202.9 & $194.3 / 198.3$ & 205.8 \\
\hline $\mathrm{Pd}-\mathrm{N}_{\mathrm{im}}$ & 209.6 & 208.3 & 209.2 & 209.5 & 220.6 & 201.6 & 208.5 \\
\hline $\mathrm{Pd}-\mathrm{S}^{-}$ & 240.2 & 239.8 & 239.6 & 239.6 & 238.4 & & 240.6 \\
\hline $\mathrm{NH}_{2}-\mathrm{Pd}-\mathrm{N}^{-}$ & 79.3 & 91.7 & 90.8 & 90.8 & 87.4 & & 80.5 \\
\hline $\mathrm{N}^{-}-\mathrm{Pd}-\mathrm{N}_{\mathrm{im}}$ & 97.8 & 85.9 & 85.4 & 85.4 & 97.0 & & 92.3 \\
\hline $\mathrm{N}_{\mathrm{im}}-\mathrm{Pd}-\mathrm{S}^{-}$ & 92.5 & 94.0 & 94.7 & 94.7 & 97.2 & & 96.4 \\
\hline $\mathrm{S}^{-}-\mathrm{Pd}-\mathrm{NH}_{2}$ & 90.4 & 88.1 & 89.4 & 89.4 & 81.2 & & 91.3 \\
\hline
\end{tabular}

a Distances reported in $\mathrm{pm}$ and angles in ${ }^{\circ}$.

b $\mathrm{X}$-ray structure reported in Ref. [30]. 
equilibrium and spectroscopic conditions the same species could be measured.

\section{Copper(II) complexes of AHAAAC-NH}

In the case of this ligand the spectroscopic methods were in the focus of the experiments to avoid the possibility the redox reactions during the potentiometric measurements. Electronic absorption spectra of $\mathrm{Cu}(\mathrm{II})$ :AHAAAC-NH $\mathrm{N}_{2}$ system were first recorded at slightly acidic $\mathrm{pH}$. Absorption maximum is detected at $596 \mathrm{~nm}$ that strongly supports the coordination of $3 \mathrm{~N}$ around copper(II). It means that the coordination sphere is unsaturated that can be completed with the coordination of thiolate group by increasing $\mathrm{pH}$. The formation of $\mathrm{MLH}_{-1}$ species was also reported in the case of nickel(II) and zinc(II), however, the complex formation processes of nickel(II) and zinc(II) started with the formation of amino and imidazole coordinated species supported with macrochelation of the thiolate and the following step was the deprotonation and coordination of the peptide nitrogen. In contrast, the complex formation of $\mathrm{Cu}(\mathrm{II})$ :AHAAAC- $\mathrm{NH}_{2}$ system can start with the coordination via amino, amide and imidazole group in acidic $\mathrm{pH}$, while the formation of the $\mathrm{MLH}_{-1}$ species corresponds the deprotonation and coordination of thiolate group. Electronic UV-vis spectra were also recorded under anaerobic conditions at $\mathrm{pH}$ 9.8. It is well known that the blue copper proteins have interesting spectroscopic properties because of their intense blue color originating from a sulfur to copper(II) ligand to metal charge transfer (LMCT) band around $600 \mathrm{~nm}$. In good agreement with the data established from the literature ${ }^{12}, \mathrm{~S}^{-} \rightarrow \mathrm{Cu}(\mathrm{II})$ chargetransfer band with high intensity was observed at $300 \mathrm{~nm}$ and $\mathrm{d}$-d transition at $580 \mathrm{~nm}$ with lower extinction coefficient that can be explained by the existence of tetragonally distorted octahedral copper(II) complexes. Electronic absorption spectra are plotted in Figure 7.

Recording the characteristic EPR spectra provides probably the most convincing proof for the absence of redox reaction between copper(II) ions and the peptide AHAAAC-NH . The spectra recorded at physiological $\mathrm{pH}$ are very similar to those reported for related ligands (AHAAAHG ${ }^{28}$ ) and the extracted parameters $g_{\|}=2.231$ and $A_{\|}=192 \times 10^{-4} \mathrm{~cm}^{-1}$ correspond well to the $\left(\mathrm{NH}_{2}, \mathrm{~N}^{-}, \mathrm{N}_{\mathrm{im}}\right)$ coordination mode (Figure $\mathrm{S} 3$ ).

The redox activity of AAHAAC- $\mathrm{NH}_{2}$ and AHAAAC- $\mathrm{NH}_{2}$ with copper(II) ion are different from each other, in the case of AAHAAC- $\mathrm{NH}_{2}$ the saturated coordination sphere is able to hinder the redox reaction in the slightly acid and neutral solution and suppress in the alkaline $\mathrm{pH}$ range because of the reduction potential of $\mathrm{Cu}(\mathrm{I}) / \mathrm{Cu}(\mathrm{II})$ is out of the range that can be reduced by the thiolate group. In contrast, copper(II) complex of AHAAAC- $\mathrm{NH}_{2}$ is a $3 \mathrm{~N}$ coordinated species with unsaturated coordination environment, therefore may give greater opportunity for redox reactions.

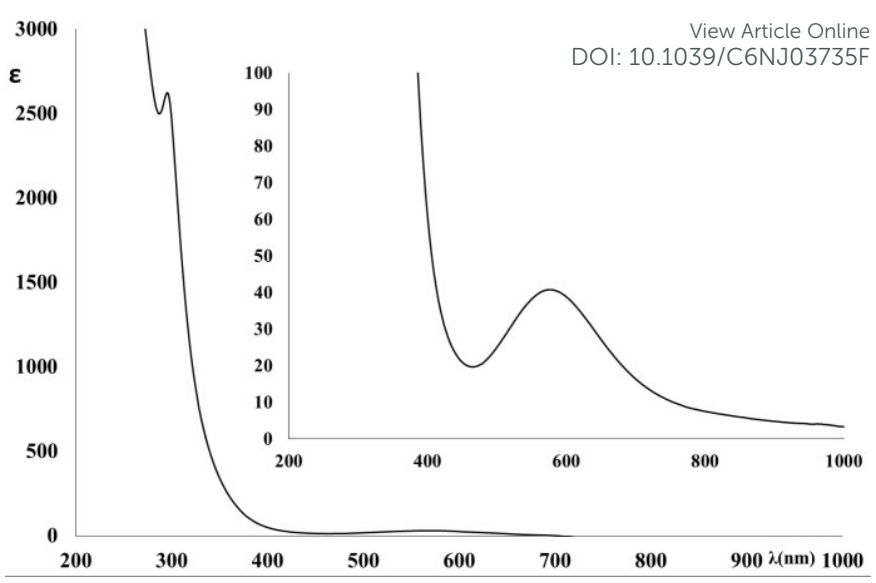

Figure 7. UV-vis spectra of the $\mathrm{MLH}_{-1}$ complex recorded in the $\mathrm{Cu}(\mathrm{II})$ :AHAAAC- $\mathrm{NH}_{2}$ 1:1 system at $\mathrm{pH} 9.8$.

\section{Palladium(II) complexes of AHAAAC- $\mathrm{NH}_{2}$}

In the presence of palladium(II) the complex formation processes are similar to those of AAHAAC- $\mathrm{NH}_{2}$, namely, three different species could be calculated on the base of equilibrium data (The concentration distribution and stepwise protonation constants are plotted in ESI, Figure S4).

The complex formation processes were followed by means of ${ }^{1} \mathrm{H}$ NMR spectroscopy. Imidazole $\mathrm{CH}$ and methine proton of $\mathrm{N}$ terminal alanine were good indicators to determine the coordinated donor groups in the $\mathrm{MLH}, \mathrm{ML}$ and $\mathrm{MLH}_{-1}$ complexes. In the case of MLH complex, two imidazole signals could be measured with different chemical shift indicating the presence of two coordination isomers. To compare the $\mathrm{N}$ terminal methine proton in the free ligand and in the complex, the amino group is coordinated in the MLH complex because the chemical shift of the Ala(1) CH shows significant differences. Based on these facts the MLH complex means two coordination isomers, where the $\mathrm{N}$-terminal group and histidine imidazole or cysteine thiolate are coordinated. The following process is the deprotonation and coordination of imidazole $\mathrm{N}$ or thiolate $\mathrm{S}$, where the ligand is coordinated to the metal ion tridentately. Similarly to palladium(II) complex of AAHAAC- $\mathrm{NH}_{2}$, the deprotonation and coordination of peptide nitrogen is shifted to the alkaline $\mathrm{pH}$ range that has been suggested by NMR and $\mathrm{CD}$ spectroscopy as well. Considerable change of chemical shift of imidazole resonances was observed above $\mathrm{pH} 7$ that can be supposed by the presence of the negatively charged amide- $\mathrm{N}$ in the vicinity of histidine. $C D$ spectra indicate also the reorganization of coordination sphere of palladium(II), which is due to the participation of the peptide nitrogen in the metal binding. $\mathrm{pH}$-dependent ${ }^{1} \mathrm{H}$ NMR spectra of the aromatic region are plotted in Figure 8.

With the help of DFT, the optimized structure of $\mathrm{PdLH}_{-1}$ was calculated. It is important to note that very similar distances were calculated in the case of $\mathrm{MLH}_{-1}$ of AAHAAC- $\mathrm{NH}_{2}$ and AHAAAC- $\mathrm{NH}_{2}$ indicating the same coordination environment of palladium(II) (see Table 1.). This observation indicates that both peptides form complexes with similar coordination geometry 

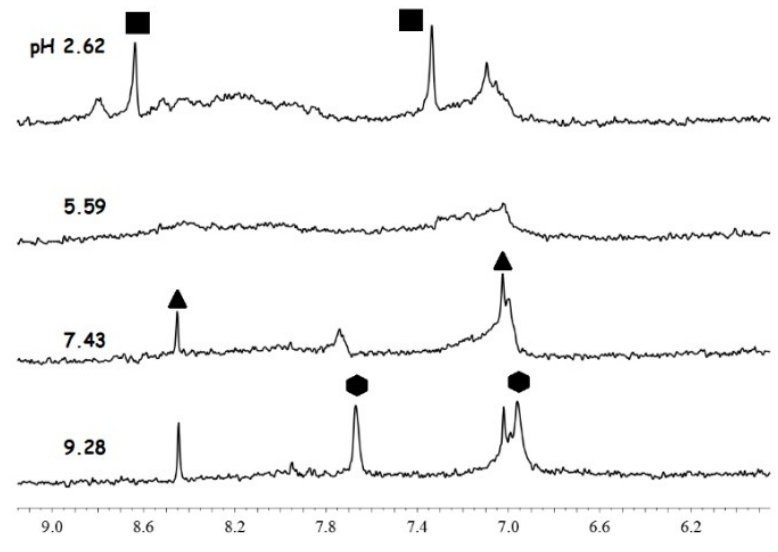

Figure 8. Selected region of $\mathrm{pH}$ dependent ${ }^{1} \mathrm{H}$ NMR spectra recorded in the $\mathrm{Pd}(\mathrm{II})$ :AHAAAC- $\mathrm{NH}_{2}$ 1:1 system. The following symbols are represented the species: $\mathrm{MLH} \mathbf{\square}, \mathrm{ML} \boldsymbol{\triangle}, \mathrm{MLH}_{-1}$

through the coordination of amino, peptide- $\mathrm{N}$, imidazole- $\mathrm{N}$ and thiolate donor groups.

The existence of the $\left(\mathrm{NH}_{2}, \mathrm{~N}^{-}, \mathrm{N}_{\mathrm{im}}, \mathrm{S}^{-}\right)$coordination mode was also confirmed by theoretical calculations. By using TD-DFT ECD spectrum was predicted and compared with the experimental one. Very good agreement and good relative error were found with the experimental spectrum. Wavelength range from 250 to $400 \mathrm{~nm}$ was compared with the experimental spectrum where two transitions could be found on $365 \mathrm{~nm}$ with $4.3 \%$ relative error and on $267 \mathrm{~nm}$ with $3.0 \%$ relative error. The experimental and calculated spectra are available in ESI, Figure S5 and S6.

\section{Conclusions}

Huge number of literature studies proves the outstanding metal binding ability of the albumin-like binding sites containing histidine in position- 3 from the amino terminus. Our previous studies on related ligands revealed that the predominance of metal binding at this site is not much affected even by the presence of another distant histidyl residue. ${ }^{28}$ Moreover, the results reported for the nickel(II) complexes of AAHAAC- $\mathrm{NH}_{2}$ led to similar conclusion and the thiolate of cysteine can only be considered as a secondary binding site for the formation of dinuclear species. ${ }^{14}$ In this study the copper(II) and palladium(II) complexes of AAHAAC- $\mathrm{NH}_{2}$ and AHAAAC- $\mathrm{NH}_{2}$ were studied and a much more pronounced effect of the distant cysteinyl residues on the metal binding of the amino terminus was obtained. In the case of copper(II)-AAHAAC- $\mathrm{NH}_{2}$ system the $\left(\mathrm{NH}_{2}, \mathrm{~N}^{-}, \mathrm{N}^{-}, \mathrm{N}_{\mathrm{im}}\right)$ coordination mode hindered the interaction between copper(II) ion and thiolate group preventing the redox reactions in acidic and neutral solution. In contrast with nickel(II) containing systems, the excess of copper(II) ions, however, does not promote dinuclear complex formation but redox reactions can occur under this condition. The suppress of redox reactions between copper(II) ions and the peptide AHAAAC- $\mathrm{NH}_{2}$ was also observed in equimolar samples but in this case the existence of $\mathrm{Cu}(\mathrm{II})-\mathrm{S}$ (thiolate) binding was demonstrated in the alkaline $\mathrm{pH}$ range.
Palladium(II) is known as the most effective metal ion to ind hice

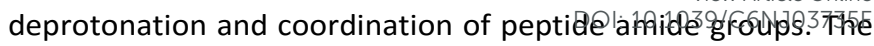
results of this study unambiguously prove that the $\mathrm{Pd}$ $S$ (thiolate) binding modes dominate over the formation of the $\mathrm{Pd}-\mathrm{N}$ (amide) bonds even if the thiolate residues are involved in various macrochelates only. The thiolate group of cysteinyl residue was described as the primary ligating site for both peptides and the remaining coordination sites were occupied by the amino, imidazole and one amide nitrogen donor atoms.

\section{Acknowledgements}

This work was supported by the Hungarian Scientific Research Fund (K 115480), Richter Gedeon Talentum Foundation and EU and co-financed by the European Regional Development Fund under the project GINOP-2.3.2-15-2016-00008. The authors thank for the National Information Infrastructure Development Institute (NIIF) for awarding access to resource based in Hungary at Debrecen and Szeged.

\section{References}

1 H. Sigel, R. B. Martin, Chem. Rev., 1982, 82, 385-426.

2 I. Sóvágó, C. Kállay, K. Várnagy, Coord. Chem. Rev., 2012, 256, 2225-2233.

3 I. Sóvágó, K. Ősz, Dalton Trans., 2006, 3841-3854.

4 H. Kozlowski, W. Bal, M. Dyba, T. Kowalik-Jankowska, Coord. Chem. Rev., 1999, 184, 319-346.

5 I. Sóvágó, K. Várnagy, N. Lihi, Á. Grenács, Coord. Chem. Rev., 2016, 327-328, 43-54.

6 Cs. G. Ágoston, T. Kowalik-Jankowska, I. Sóvágó, J. Chem. Soc. Dalton Trans., 1999, 3295-3302.

7 D. Witkowska, M. Rowinska-Zyrek, G. Valensin, H. Kozlowski, Coord. Chem. Rev., 2012, 256, 133-148.

8 M. Rowinska-Zyrek, D. Witkowska, D. Valensin, M. Kamysz, H. Kozlowski, Dalton Trans., 2010, 39, 5814-5826.

9 S. Potocki, D. Valensin, H. Kozlowski, Dalton Trans., 2014, 43, 10215-10223.

10 D. Árus, Á. Dancs, N. V. Nagy, T. Gajda, Dalton Trans., 2013, 42, 12031-12040.

11 E. I. Solomon, J. W. Hare, H. B. Gray., Proc. Natl. Acad. Sci. USA, 1976, 73, 1389-1393.

12 R. G. Daugherty, T. Wasowicz, B. R. Gibney, V. J. DeRose, Inorg. Chem., 2002, 41, 2623-2632.

13 N. Lihi, Á. Grenács, S. Timári, I. Turi, I. Bányai, I. Sóvágó, K. Várnagy, New, J. Chem., 2015, 39, 8364-8372.

14 M. Raics, N. Lihi, A. Laskai, C. Kállay, K. Várnagy, I. Sóvágó, New J. Chem., 2016, 40, 5420-5427.

15 G. Gran, Acta Chem. Scan., 1950, 4, 559-577.

16 H. Irving, G. Miles, L. D. Pettit, Anal. Chim. Acta, 1967, 38, 475488.

17 P. Gans, A. Sabatini, A. Vacca, J. Chem. Soc, Dalton Trans., 1985, 1195-1200.

18 L. Zékány, I. Nagypál, D. Leggett (Ed), in: Computational Methods for the Determination of Stability Constants, Plenum Press, New York, 1985, 291-299.

19 C. S. Johnson, Prog. Nucl. Magn. Reson. Spectrosc., 1999, 34, 203-256.

20 M. Holz, S. R. Heil and A. Sacco, Phys. Chem. Chem. Phys., 2000, 2, 4740-4742.

21 M. J. Frisch, G. W. Trucks, G. E. S. H. B. Schlegel, M. A. Robb, J. R. Cheeseman, G. Scalmani, V. Barone, B. Mennucci, G. A. Petersson, H. Nakatsuji, M. Caricato, X. Li, H. P. Hratchian, A. 
F. Izmaylov, J. Bloino, G. Zheng, J. L. Sonnenberg, M. Hada, M. Ehara, K. Toyota, R. Fukuda, J. Hasegawa, M. Ishida, T. Nakajima, Y. Honda, O. Kitao, H. Nakai, T. Vreven, J. A. Montgomery, Jr., J. E. Peralta, F. Ogliaro, M. Bearpark, J. J. Heyd, E. Brothers, K. N. Kudin, V. N. Staroverov, R. Kobayashi, J. Normand, K. Raghavachari, A. Rendell, J. C. Burant, S. S. Iyengar, J. Tomasi, M. Cossi, N. Rega, J. M. Millam, M. Klene, J. E. Knox, J. B. Cross, V. Bakken, C. Adamo, J. Jaramillo, R. Gomperts, R. E. Stratmann, O. Yazyev, A. J. Austin, R. Cammi, C. Pomelli, J. W. Ochterski, R. L. Martin, K. Morokuma, V. G. Zakrzewski, G. A. Voth, P. Salvador, J. J. Dannenberg, S. Dapprich, A. D. Daniels, Ö. Farkas, J. B. Foresman, J. V. Ortiz, J. Cioslowski, D. J. Fox, Gaussian 09, Gaussian Inc., Wallingford CT, 2009.

22 A. D. Becke, J. Chem. Phys., 1993, 98, 5648-5652.

23 E. Runge, E. K. U. Gross, Phys. Rev. Lett., 1984, 52, 997-1000.

24 A. D. Becke, J. Chem., Phys., 1993, 98, 1372-1377.

25 T. Yanai, D. P. Tew, N. C. Handy, J. Chem. Phys., 2004, 393, 51057.

26 T. Lu, F. Chen, J. Comp. Chem. 2012, 33, 580-592.

27 N. Camerman, A. Camerman and B. Sarkar, Can. J. Chem., 1976, 54, 1309-1316.

28 Á. Grenács, A. Kaluha, C. Kállay, V. Jószai, D. Sanna, I. Sóvágó, J. Inorg. Biochem., 2013, 128, 17-25.

29 E. W. Wilson, R. B. Martin, Inorg. Chem., 1970, 9, 528-532.

30 S. L. Best, T. K. Chattopadhyay, M. I. Djuran, R. A. Palmer, P. J. Sadler, I. Sóvágó, K. Várnagy, J. Chem. Soc., Dalton Trans., 1997, 2587-2596.

31 H. F. Stanyon, X. Cong, Y. Chen, N. Shahidullah, G. Rossetti, J. Dreyer, G. Papamokos, P. Carloni, J. H. Viles, FEBS Journal, 2014, 281, 3945-3954.

32 S. E. Harnung, E. Larsen, Coord. Chem. Rev., 2016, 307, 81-103.

33 P. P. Corby, F. Cagnin, A. C. Massabni, J. Coord. Chem., 2009, 62, 2764-2771.

34 A. Yokoi, N. Yoshinari, T. Konno, J. Incl. Phenom. Macro. Chem., 2015, 82, 123-133. 


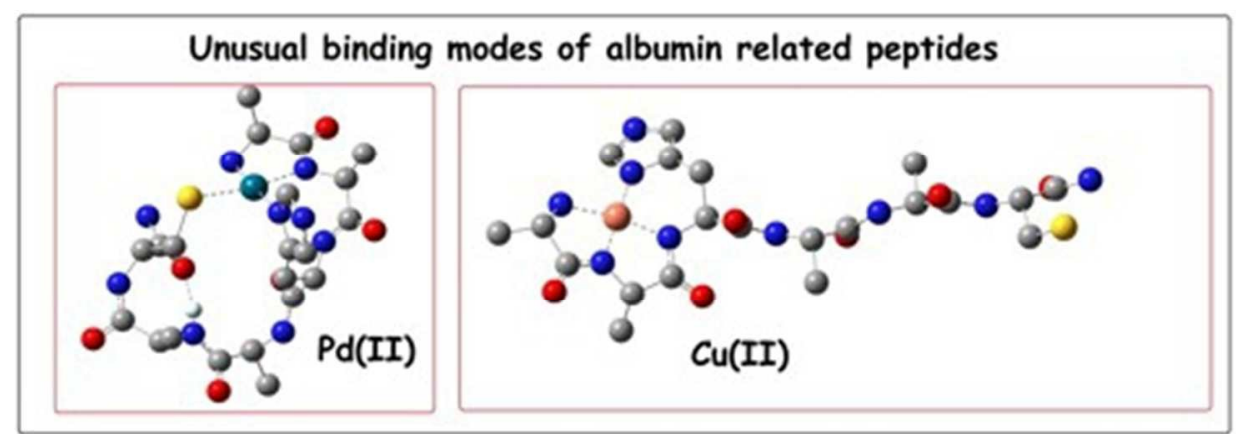

$80 \times 28 m m(150 \times 150$ DPI $)$ 